\title{
Analysis of the legal and technical condition regarding the possibility of implementation light metro class transport solutions in Poland
}

\section{Analiza stanu prawnego i technicznego dotycząca możliwości wdrożenia w Polsce rozwiązań transportowych klasy lekkiego metra}

The article presents a technical analysis of the transport systems currently existing on the market for "other rail transport" within the meaning of the act on public collective transport, i.e. other than railway transport. Transport subsystems were analyzed in terms of technical, operational, and functional. Identification of a key and problematic records in legal acts regarding the analyzed class of transport solutions was carried out, in the field of infrastructure and rolling stock subsystems. The current legal status in Poland does not prohibit the use of transport solutions of metro class, such as monorail or APM (Automated People Mover), which are unusual in the country (and successfully operating in the world).

A new classification of rail transport was proposed taking into account similarities in technical, and operational-functional parameters as well as subordination to supervisory and safety authorities. Due to the similarity, rail vehicles traveling on the single rail (monorail), and APM were recognized as a metro variant.

A proposal for changes and new provisions in the acts of supplementary significance was presented, due to the possibility of allowing new metro class transport solutions to be used in Poland.

Changes in legislation should concern on introduction of new means of transport, such as monorail and APM, to the legal acts and defined them as metro variants. The lack of a general definition of a metro, in the legal acts on rail transport and public collective transport, may in the future hamper the launch of new transport solutions in transport projects in large cities. The definitions currently used in Polish legislation do not describe all means of transport, which are already widely used in many places around the world and in Europe.

$W$ artykule przeprowadzono analize techniczna aktualnie istniejacych na rynku rozwiqzań systemów transportowych dla ,transportu innego szynowego" $w$ rozumieniu ustawy o publicznym transporcie zbiorowym, tzn. innego niż transport kolejowy. Podsystemy transportowe analizowano pod względem technicznym $i$ eksploatacyjno-funkcjonalnym. Przeprowadzono również identyfikacje kluczowych i problematycznych zapisów $w$ aktach prawnych dotyczacych analizowanej klasy rozwiazan transportowych, w zakresie podsystemów infrastruktura i tabor.

Obecny stan prawny $w$ Polsce nie zabrania stosowania nietypowych $w$ kraju (a z powodzeniem funkcjonujacych w świecie) rozwiqzań transportowych klasy lekkiego metra, jak monorail czy APM (Automated People Mover).

Zaproponowano nowy podziat transportu szynowego uwzględniajacy podobieństwa parametrów technicznych $i$ eksploatacyjno-funkcjonalnych oraz podległość do organów nadzoru i bezpieczeństwa. Ze względu na podobieństwo uznano środki transportu poruszajace się po jednej szynie (monorail) i APM jako odmiany lekkiego metra.

Przedstawiono propozycje zmian i nowych zapisów w ustawach o znaczeni: uzupetniajacym, ze względu na możliwości dopuszczenia nowych rozwiqzań transportowych klasy lekkiego metra do eksploatacji w Polsce.

Zmiany $w$ prawodawstwie dotyczyć powinny wprowadzenia do ustaw nowych środków transportu jak lekkie metro, w tym monorail i APM, zdefiniowanych jako odmiany metra. Brak ogólnej definicji metra $w$ ustawach o transporcie kolejowym $i$ publicznym transporcie zbiorowym może $w$ przyszłości utrudniać wprowadzenie nowych rozwiqzań do realizacji $w$ ramach projektów transportowych duzych miast. Stosowane aktualnie $w$ polskim prawodawstwie definicje nie opisujq wszystkich środków transportu, które sa już powszechnie stosowane w wielu miejscach na świecie i Europie. 


\section{INTRODUCTION}

The need to take up the topic of work resulted from the development of transport technology and the growing demand for modern transport solutions as well as the emerging demand for this type of transport in our country and Europe. Examples include:

- $\quad$ plans to build a Central Communication Port with the use of monorail or APM,

- plans to build a monorail line in Rzeszów,

- the concept of the Metropolitan Railway for the Metropolis GZM, the proposed monorail line Katowice-Pyrzowice Airport and the need to increase rail transport in GZM,

- plans for the construction of a "metro" in Krakow;

- planned transition to ATO / CBTC control in the Warsaw Metro,

- $\quad$ presence of producers of new transport solutions in Poland (Bombardier, Alstom).

- implementation of APM at the airports in Munich and Frankfurt,

- implementation of APM in Venice (ferry port transfer center).

The means of metropolitan transport, such as "light metro", including monorail and APM, appear in the Polish transport literature since the 1960s [1-4]. Although these sources treat the discussed solutions as unconventional, they cannot be treated as unconventional with today's construction and engineering techniques, light construction materials and modern control systems.

\section{UMIEJSCOWIENIE ROZWIĄZAŃ TYPU MONORAIL I APM W KLASYFIKACJI ŚROD- KÓW TRANSPORTU SZYNOWEGO}

Dla umiejscowienia rozwiązań transportowych typu monorail i APM przeprowadzono analizę techniczna aktualnie istniejących na rynku rozwiązań systemów transportowych dla „transportu innego szynowego" w rozumieniu ustawy o publicznym transporcie zbiorowym [5], tzn. innego niż transport kolejowy. Podsystemy transportowe analizowano pod względem technicznym i eksploatacyjno-funkcjonalnym (tablica 1).

Analizowano środki transportu, takie jak:

- klasyczne (ciężkie) metro,

- lekkie metro,

- monorail,

- APM,

- szybki tramwaj,

- tramwaj.

\section{WSTĘP}

Potrzeba podjęcia tematu pracy wyniknęła $\mathrm{z}$ rozwoju techniki transportowej i wzrostu zapotrzebowania na nowoczesne rozwiązania transportowe oraz $z$ rodzącego się w naszym kraju i Europie zapotrzebowania na tego typu środki transportu. Jako przykłady należy wymienić:

- plany budowy Centralnego Portu Komunikacyjnego $\mathrm{z}$ wykorzystaniem monoraila lub APM,

- plany budowy linii monoraila w Rzeszowie,

- koncepcję Kolei Metropolitalnej dla Górnośląsko-Zagłębiowskiej Metropoli, proponowana linia monoraila Katowice-Port Lotniczy Pyrzowice oraz potrzeba zwiększenia przewozów transportem szynowym w GZM,

- plany budowy „metra” w Krakowie;

- planowane przejście na ATO/CBTC w Metrze Warszawskim,

- obecność producentów nowych rozwiązań transportowych w Polsce (Bombardier, Alstom).

- wdrożenie do stosowania APM w portach lotniczych w Monachium i Frankfurcie,

- wdrożenie APM w Wenecji (port promowy centrum przesiadkowe).

Środku transportu metropolitalnego, jak lekkie metro, $\mathrm{w}$ tym monorail i APM pojawiają się $\mathrm{w}$ polskiej literaturze transportowej już od lat 60 ubiegłego wieku [1-4].

Wprawdzie źródła te traktują omawiane rozwiązania jako niekonwencjonalne, ale przy dzisiejszej technice budowlanej, inżynieryjnej, lekkich materiałach konstrukcyjnych i nowoczesnych systemach sterowania nie można ich traktować jako niekonwencjonalne.

\section{UMIEJSCOWIENIE ROZWIĄZAŃ TYPU MONORAIL I APM W KLASYFIKACJI ŚROD- KÓW TRANSPORTU SZYNOWEGO}

Dla umiejscowienia rozwiązań transportowych typu monorail i APM przeprowadzono analizę techniczna aktualnie istniejących na rynku rozwiązań systemów transportowych dla „transportu innego szynowego" w rozumieniu ustawy o publicznym transporcie zbiorowym [5], tzn. innego niż transport kolejowy. Podsystemy transportowe analizowano pod względem technicznym i eksploatacyjno-funkcjonalnym (tablica 1).

Analizowano środki transportu, takie jak:

- klasyczne (ciężkie) metro,

- lekkie metro,

- monorail,

- APM,

- szybki tramwaj,

- tramwaj. 


\begin{tabular}{|c|c|c|c|c|c|c|}
\hline Fir & System feathries & $\begin{array}{c}\text { Classic (heary) } \\
\text { metro }\end{array}$ & $\begin{array}{l}\text { Light metro, } \\
\text { monorail, APM }\end{array}$ & Fast tram & Tram & Comments \\
\hline \multicolumn{7}{|c|}{ General characteristics of the transport subsystem } \\
\hline 1 & $\begin{array}{l}\text { The method of separat- } \\
\text { ing the infrastructure }\end{array}$ & $\begin{array}{l}\text { Lack of collision } \\
\text { with other subsys- } \\
\text { tems }\end{array}$ & $\begin{array}{l}\text { Lack of collision } \\
\text { with other sub- } \\
\text { systems }\end{array}$ & $\begin{array}{l}\text { Limited collision } \\
\text { with other subsys- } \\
\text { tems }\end{array}$ & $\begin{array}{l}\text { Collisions with } \\
\text { other subsys- } \\
\text { tems }\end{array}$ & \\
\hline 2 & $\begin{array}{l}\text { Tramsport capacity } \\
\text { [pplpd] }\end{array}$ & $\begin{array}{l}30000- \\
100000\end{array}$ & $\begin{array}{l}3000- \\
45000 \\
\end{array}$ & $\begin{array}{l}3000- \\
18000\end{array}$ & $\begin{array}{l}3000- \\
10000\end{array}$ & \\
\hline 3 & $\begin{array}{l}\text { Maximmm design } \\
\text { speed [am } \mathrm{h}]\end{array}$ & $80-90$ & $80\left(100^{4}\right)$ & $60-75$ & 60 & $\begin{array}{l}\text { "Irrovia } 300 \\
\text { Metro }\end{array}$ \\
\hline 4 & $\begin{array}{l}\text { Commercial speed } \\
\text { [am/h] }\end{array}$ & $30-40$ & $30-40$ & $20-25$ & $15-20$ & \\
\hline 5 & $\begin{array}{l}\text { Time spacing (head- } \\
\text { woy) max. [min] }\end{array}$ & 1.5 & 1.5 & 1.5 & 1.5 & In rush hour \\
\hline 6 & $\begin{array}{l}\text { Safety suervisory sul- } \\
\text { thority }\end{array}$ & UTK & UTK $^{*}$ & $\begin{array}{l}\text { GDDKiÁ } \\
\text { IPSz TABOR }\end{array}$ & $\begin{array}{l}\text { GDDKiÄ } \\
\text { IPSz TABOR }\end{array}$ & in Poland \\
\hline \multicolumn{7}{|c|}{ Infrastructure characteristics } \\
\hline 7 & Line routing & Mainly in a torrel & $\begin{array}{l}\text { On suriace, on an } \\
\text { estacade, in a } \\
\text { tornel }\end{array}$ & $\begin{array}{l}\text { On surface, on an } \\
\text { estacade, in a tom- } \\
\text { nel }\end{array}$ & On surfice & in Poland \\
\hline 8 & Track & $\begin{array}{l}\text { UTC steel rails } \\
49 \mathrm{El}, 60 \mathrm{El} \mathrm{-} \\
\text { track gauge } 1435 \\
\mathrm{~mm}\end{array}$ & $\begin{array}{l}\text { UIC steel rails } \\
49 \mathrm{El}, 60 \mathrm{El}- \\
\text { track grouge } 1435 \\
\text { mm; concrete } \\
\text { quide beam }\end{array}$ & $\begin{array}{l}\text { UIC steel rails - } \\
\text { track gauge } 1435 \\
\text { or } 1000 \mathrm{~mm} \text {; } \\
\text { grooved (girder) } \\
\text { rails }\end{array}$ & $\begin{array}{l}\text { UIC steel rails } \\
\text { - track gauge } \\
1435 \text { or } 1000 \\
\text { mm; grooved } \\
\text { (girder) rails }\end{array}$ & $\begin{array}{l}\text { Tramway track } \\
\text { gauge } 1000 \mathrm{~mm} \\
\text { sise in: Tonní, } \\
\text { Łódx́, Bydgosex, } \\
\text { ETblag and } \\
\text { Grudxiadx }\end{array}$ \\
\hline 9 & Power suply & $\begin{array}{l}750 \mathrm{~V} \mathrm{DC}, \\
\text { third rail }\end{array}$ & $\begin{array}{l}600-750 \mathrm{VDC}, \\
\text { third rail }\end{array}$ & $\begin{array}{l}600 \mathrm{VDC}, \text { cate- } \\
\text { nary }\end{array}$ & $\begin{array}{l}600 \mathrm{VDC}, \\
\text { catenary }\end{array}$ & in Polsind \\
\hline 10 & $\begin{array}{l}\text { Distance between } \\
\text { stops }[\mathrm{m}]\end{array}$ & $600-1200$ & $600-1200$ & $400-800$ & $400-600$ & \\
\hline 11 & $\begin{array}{l}\text { Cortrol command and } \\
\text { signaling }\end{array}$ & $\begin{array}{l}\text { Automatic line } \\
\text { block system, } \\
\text { CBT C } \\
\text { (Commmications- } \\
\text { based train } \\
\text { control)* }\end{array}$ & CBTC & $\begin{array}{l}\text { Ponring on sight, } \\
\text { adsptive signaling }\end{array}$ & $\begin{array}{l}\text { Fonming on } \\
\text { sight }\end{array}$ & in Poland \\
\hline 12 & Train control & $\begin{array}{l}\text { With diver or } \\
\text { driverless } \\
\text { GoA } 4^{\text {k }}\end{array}$ & $\begin{array}{l}\text { With driver or } \\
\text { driverless } \\
\text { GoA } 4\end{array}$ & With driver & With driver & \\
\hline 13 & $\begin{array}{l}\text { Additional security } \\
\text { elements }\end{array}$ & $\begin{array}{l}\text { Autromatic plat- } \\
\text { form doors" }\end{array}$ & $\begin{array}{l}\text { Autromatic plat- } \\
\text { form doors }\end{array}$ & & & \\
\hline \multicolumn{7}{|c|}{ Vehicle charateristics } \\
\hline 14 & $\begin{array}{l}\text { Train consist [trin } \\
\text { car] }\end{array}$ & $6-12$ & $1-8$ & $2-6$ & $1-4$ & $\begin{array}{l}\text { B T Monorail 2-8; } \\
\text { BT APM 1-6; } \\
\text { Irovovia Metro 1- } \\
6 \text {; } \\
\text { Alstom Axoris 2- } \\
5\end{array}$ \\
\hline 15 & $\begin{array}{l}\text { Car capacify [passen- } \\
\text { ger] at } 6 \mathrm{pass} . \mathrm{m}^{2}\end{array}$ & $250-280$ & $140-255$ & $70-140$ & $70-140$ & $\begin{array}{l}\text { BT Monorail 140; } \\
\text { BT APM } 103 \text {; } \\
\text { BT Irrovia Metro } \\
\text { UI to } 255 \text {; } \\
\text { Alstom Axoris } \\
200 \text {; Konstal } \\
\text { 105H- } 136\end{array}$ \\
\hline 16 & Car width [m] & $2,7-2,9$ & $2,7-3,14$ & $2,2-2,5$ & $2,2-2,5$ & $\begin{array}{l}\text { BT Monorail } \\
3.14 ; \text { BT APM } \\
2.85, \text { Alstam } \\
\text { Axonis } 2.7\end{array}$ \\
\hline 17 & $\begin{array}{l}\text { Minimm horixortal } \\
\text { onve radius and } \\
\text { maximmm gradient }\end{array}$ & $\begin{array}{l}300-400 \mathrm{~m} \\
(90 \mathrm{~km} / \mathrm{h}) \\
70 \mathrm{~m} \text { (30 kmh) } \\
\text { Pockylenie jak dla } \\
\text { kolei }\end{array}$ & $\begin{array}{l}22-70 \mathrm{~m} \\
6-10 \%\end{array}$ & - & - & $\begin{array}{l}\text { Minimm arre } \\
\text { radius: BT Mono- } \\
\text { rail } 46 \mathrm{~m} \text { B B } \\
\text { APM } 22 \mathrm{~m} \text {; } \\
\text { Irrovia Metro } \\
70 \mathrm{~m} \text {; } \\
\text { Axomis } 45 \mathrm{~m}\end{array}$ \\
\hline
\end{tabular}

The analysis of the literature, the provisions of the acts (on railway transport and public collective transport) concerning rail transport and other rail transport, as well as the authors' own experience and technical analysis of the characteristics of transport subsystems (Table 1), allow for the division of rail transport presented in Fig. 1.
Analiza literatury, zapisów ustaw (o transporcie kolejowym i publicznym transporcie zbiorowym) dotyczących transportu szynowego i transportu innego szynowego, oraz własne doświadczenie autorów i analiza techniczna charakterystyk podsystemów transportowych (tablica 1), pozwalają na podział transportu szynowego przedstawiony na rys. 1 . 
Tablica 1. Charakterystyk podsystemów transportowych dla transportu innego szynowego [6-9]

\begin{tabular}{|c|c|c|c|c|c|c|}
\hline Lp. & Cechy systemn & Cięzie metro & $\begin{array}{l}\text { Lekkie metro, } \\
\text { monorail, APM }\end{array}$ & Syytki tramwaj & Tramwaj & Uhmagi \\
\hline \multicolumn{7}{|c|}{ Ogólna charakterystyka podsystemu transportowego } \\
\hline 1 & $\begin{array}{l}\text { Sposób wydrielenia } \\
\text { infir atruktary }\end{array}$ & $\begin{array}{l}\text { Brak kolixyjości } \\
\text { z irommi } \\
\text { podsystemami }\end{array}$ & $\begin{array}{l}\text { Brak kolixymosci } \\
\text { x irrymi } \\
\text { podsystemami }\end{array}$ & $\begin{array}{l}\text { Ogranicsona } \\
\text { kolixyjuość a } \\
\text { irrymi } \\
\text { podsystemami }\end{array}$ & $\begin{array}{l}\text { Kolizjinosc a } \\
\text { irrymi } \\
\text { podystemami }\end{array}$ & \\
\hline 2 & $\begin{array}{l}\text { Zdohość pryewowowa } \\
\text { [pphyd] }\end{array}$ & $\begin{array}{l}30000- \\
100000\end{array}$ & $\begin{array}{l}3000- \\
45000\end{array}$ & $\begin{array}{l}3000- \\
18000\end{array}$ & $\begin{array}{l}3000- \\
10000\end{array}$ & \\
\hline 3 & Pręcikośc max. [kmh] & $80-90$ & $80\left(100{ }^{4}\right)$ & $60-75$ & 60 & $\begin{array}{l}\text { ". Irrovia } 300 \\
\text { Metro }\end{array}$ \\
\hline 4 & $\begin{array}{l}\text { Prędkósc } \\
\text { komminacyina [amm] }\end{array}$ & $30-40$ & $30-40$ & $20-25$ & $15-20$ & \\
\hline 5 & $\begin{array}{l}\text { Cafstotliwosc nuchos } \\
\text { max. [min] }\end{array}$ & 1,5 & 1,5 & 1,5 & 1,5 & w szcaycie \\
\hline 6 & $\begin{array}{l}\text { Orgen nadworn } \\
\text { bexpiec zerstha }\end{array}$ & UTK & UTK* $^{*}$ & $\begin{array}{l}\text { GDDKiA } \\
\text { IPSz TABOR }\end{array}$ & $\begin{array}{l}\text { GDDKiA } \\
\text { IPSz TABOR }\end{array}$ & w Polsce \\
\hline \multicolumn{7}{|c|}{ Charskterystyka infiratruktary } \\
\hline 7 & $\begin{array}{l}\text { Sposób prowadweria } \\
\text { linii }\end{array}$ & Grómie w tomeh & $\begin{array}{l}\text { Ha powierwhui, } \\
\text { na estakadmie, w } \\
\text { tomehl }\end{array}$ & $\begin{array}{l}\text { Ha powierwhrui, } \\
\text { na estakadmie, w } \\
\text { tomehn }\end{array}$ & Ha powierzchui & w Polsce \\
\hline 8 & Tor & $\begin{array}{l}\text { Sxyry UIC } \\
\text { stalowe } 49 \mathrm{El}, \\
60 \mathrm{El}-\text { roustaw } \\
1435 \mathrm{~mm}\end{array}$ & $\begin{array}{l}\text { Sxyry UIC } \\
\text { stalowe - rowstaw } \\
1435 \mathrm{~mm} \\
\text { betonowe belki } \\
\text { prowadxqce }\end{array}$ & $\begin{array}{l}\text { Sxyry UIC } \\
\text { stalowe - rowtaw } \\
1435 \text { bub } 1000 \\
\text { mm; sayry } \\
\text { tramwajowe } \\
\text { (rowkowe) }\end{array}$ & $\begin{array}{l}\text { Sxyry UIC } \\
\text { stalowe - } \\
\text { romstiw } 1435 \\
\text { bub } 1000 \mathrm{~mm} \text {; } \\
\text { sayry } \\
\text { tramwajowe } \\
\text { (rowkowe) }\end{array}$ & $\begin{array}{l}\text { Tramwaje } \\
\text { rowstaw } 1000 \\
\text { mm w: Tonmin, } \\
\text { Eodxi, } \\
\text { Bydgoswcy, } \\
\text { Eitbligu i } \\
\text { Grudxiadme }\end{array}$ \\
\hline 9 & Zasilanie & $\begin{array}{l}750 \mathrm{WDC}, \\
3 \text { syma }\end{array}$ & $\begin{array}{l}600-750 \mathrm{VDC}, \\
3 \text { saya }\end{array}$ & $\begin{array}{l}600 \mathrm{VDC}, \text { sieć } \\
\text { trakcyina }\end{array}$ & $\begin{array}{l}600 \mathrm{VDC}, \text { sié } \\
\text { trakcyjus }\end{array}$ & w Polsce \\
\hline 10 & $\begin{array}{l}\text { Odleghosi międyy } \\
\text { parystanksmi }[\mathrm{m}]\end{array}$ & $600-1200$ & $600-1200$ & $400-800$ & $400-600$ & \\
\hline 11 & $\begin{array}{l}\text { System sterowria } \\
\text { nuchem }\end{array}$ & $\begin{array}{l}\text { Blokada } \\
\text { smoctyrura, } \\
\text { CBTC }{ }^{*}\end{array}$ & CBTC & $\begin{array}{l}\text { Jazda na } \\
\text { widocanośc, } \\
\text { syaralizacja } \\
\text { adaptacyjua }\end{array}$ & $\begin{array}{l}\text { jazda ná } \\
\text { widocmość }\end{array}$ & w Polsce \\
\hline 12 & Prowadxerie pojastu & $\begin{array}{l}\text { Zatogowe bub } \\
\text { bexustogowe } \\
\text { GoA } 4^{\text {th }}\end{array}$ & $\begin{array}{l}\text { Zatogowe hab } \\
\text { bemalogowe } \\
\text { GoA } 4\end{array}$ & zatogowe & zatogowe & \\
\hline 13 & $\begin{array}{l}\text { Dodatkowe elementy } \\
\text { bexpiec zeristwa }\end{array}$ & Drawi peronowe *t & Drwai peronowe & & & \\
\hline \multicolumn{7}{|c|}{ Charakterystyka pojaziów } \\
\hline 14 & $\begin{array}{l}\text { Licma } \\
\text { wagonómicxłonón w } \\
\text { składrie }\end{array}$ & $6-12$ & $1-8$ & $2-6$ & $1-4$ & $\begin{array}{l}\text { Monorail 2-8; } \\
\text { APM 1-6; } \\
\text { Irrovia Mitro } 1 \text { - } \\
6 \text {; } \\
\text { Axonis } 2-5\end{array}$ \\
\hline 15 & 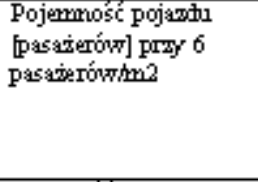 & $250-280$ & $140-255$ & $70-140$ & $70-140$ & $\begin{array}{l}\text { Monorail 140; } \\
\text { APM 103; } \\
\text { Irowovia Metro } \\
\text { do } 255 \text {; } \\
\text { Axonis } 200 \text {; } \\
\text { 105H- } 136\end{array}$ \\
\hline 16 & Syerokosi wagoral [m] & $2,7-2,9$ & $2,7-3,14$ & $2,2-2,5$ & $2,2-2,5$ & $\begin{array}{l}\text { Monorail 3,14; } \\
\text { APM } 2,85 \text {, } \\
\text { Axomis } 2,7\end{array}$ \\
\hline 17 & $\begin{array}{l}\text { Mriminatry promień } \\
\text { buku ipochylenie toru }\end{array}$ & $\begin{array}{l}300-400 \mathrm{~m} \\
90 \mathrm{~km} / \mathrm{h}) \\
70 \mathrm{~m}(30 \mathrm{kmh}) \\
\text { Podhylenie jak } \\
\text { dla kolei }\end{array}$ & $\begin{array}{l}22-70 \mathrm{~m} \\
6-10 \%\end{array}$ & $\cdot$ & $\cdot$ & $\begin{array}{l}\text { Minimatry } \\
\text { promier huks: } \\
\text { Monorail } 46 \mathrm{~m} \text {; } \\
\text { APM } 22 \mathrm{~m} \text {; } \\
\text { Irwovia Metro } \\
70 \mathrm{~m} \text {; } \\
\text { Axomis } 45 \mathrm{~m}\end{array}$ \\
\hline
\end{tabular}

At the same time, due to the similarity of technical, operational and functional parameters, means of transport moving on one rail (monorail) and APM should be considered a type of metro. The President of UTK (The Office of Rail Transport) is responsible for the approval of devices and systems used in the metro, including monorail and APM.
Jednocześnie ze względu na podobieństwo parametrów technicznych i eksploatacyjno-funkcjonalnych należy uznać środki transportu poruszające się po jednej szynie (monorail) i APM jako odmiany metra. Nadzór nad dopuszczaniem urządzeń i systemów stosowanych w metrze, w tym dla monoraila i APM stanowi Prezes UTK. 


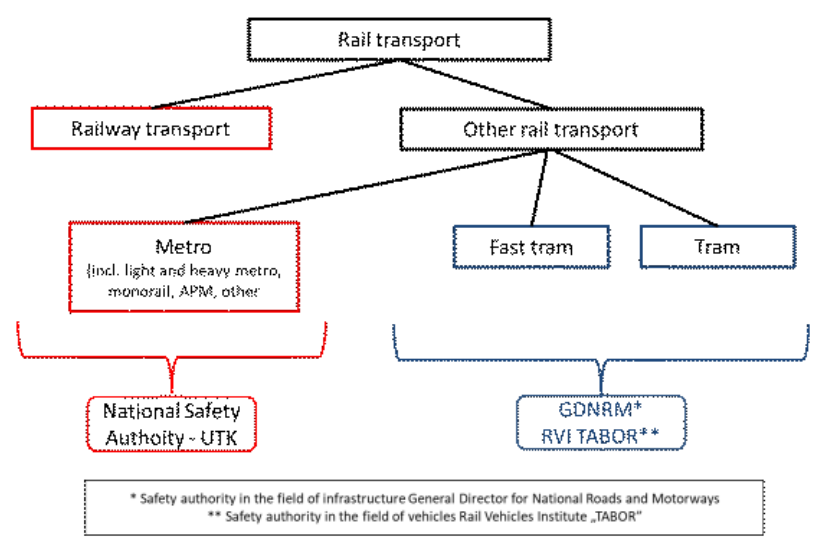

Fig. 1. The division of rail transport with reporting to the safety supervision authority

Rys. 1. Podział transportu szynowego wraz z podległością organowi nadzoru bezpieczeństwa

\section{TRANSPORT SUBSYSTEM DEFINITIONS}

The act on railway transport [10] uses the term "metro", e.g. in art. 3.1 but does not define it or link it to other documents that define the metro. Similarly, the Act on public collective transport [5] applies in art. 4.1, the concept of the metro when defining other rail transport, however, does not define metro.

After the analyses for the division of rail transport presented in Fig. 1, the following definitions of transport subsystems are proposed within other rail transport:

Metro - type of passenger transport with electric traction, carried out on a separate infrastructure, along a strictly defined track, e.g. a railroad or monorail structure, the lines of which can run in tunnels, on surface, as well as on estacades, characterized by: a complex signalling system (analogous to railway systems), high frequency of running, capacity supporting highintensity traffic, and small distances between stations, e.g. in the order of several hundred meters (definition developed by the Departments of Transport of the Warsaw University of Technology and Transport and Aviation Engineering of the Silesian University of Technology).

Heavy metro - type of passenger transport with electric traction, carried out on a separate infrastructure, along a strictly defined railroad, the lines of which are run, in particular, in tunnels, and their capacity ensures high-intensity traffic; for which the requirements in Poland are specified in the Ordinance of the Minister of Infrastructure of 17 June 2011 on the technical conditions to be met by metro structures and their location [11].

Light metro - type of urban or suburban passenger transport carried out on a separate infrastructure, along a strictly defined track, e.g. a railroad or a monorail structure. Light metro lines can run in tunnels, on surface, as well as on estacades, and their ca-

\section{DEFINICJE PODSYSTEMÓW TRANSPOR- TOWYCH}

Ustawa o transporcie kolejowym [10] stosuje pojęcie metra, np. w art. 3.1, ale go nie definiuje ani nie odsyła do innych dokumentów definiujących metro. Podobnie ustawa o publicznym transporcie zbiorowym [5] stosuje $\mathrm{w}$ art. 4.1 pojęcie metra przy definiowaniu transportu innego szynowego, nie podaje jednak definicji metra.

Po dokonaniu analiz na potrzeby podziału transportu szynowego przedstawionego na rys. 1 proponuje sie następujące definicje podsystemów transportowych, w zakresie transportu innego szynowego:

Metro - rodzaj transportu pasażerskiego o trakcji elektrycznej, realizowanego na infrastrukturze wydzielonej, po ściśle określonym torze jazdy np. drodze szynowej lub konstrukcji jednoszynowej, którego linie mogą być prowadzone w tunelach, po powierzchni terenu, a także na estakadach, cechujący się: złożonym systemem sygnalizacji (analogicznym do systemów kolejowych), dużą częstotliwością kursowania, zdolnością przepustową realizującą obsługę ruchu o dużym nasileniu oraz małymi odległościami pomiędzy stacjami, np. rzędu kilkuset metrów (definicja opracowana przez Wydziały Transportu Politechniki Warszawskiej oraz Transportu i Inżynierii Lotniczej Politechniki Śląskiej).

Ciężkie metro - rodzaj transportu pasażerskiego o trakcji elektrycznej, realizowanego na infrastrukturze wydzielonej, po ściśle określonej drodze szynowej, którego linie prowadzone są w szczególności w tunelach, a ich zdolność przepustowa zapewnia obsługe ruchu o dużym nasileniu; dla którego wymagania określa Rozporządzenie Ministra Infrastruktury z dnia 17 czerwca 2011 r. w sprawie warunków technicznych, jakim powinny odpowiadać obiekty budowlane metra i ich usytuowanie [11].

Lekkie metro - rodzaj miejskiego lub podmiejskiego transportu pasażerskiego realizowanego na infrastrukturze wydzielonej, po ściśle określonym torze jazdy np. drodze szynowej lub konstrukcji jednoszynowej. Linie lekkiego metra mogą być prowadzone w tunelach, po powierzchni terenu, a także na estakadach, a ich zdolność przepustowa zapewnia obsługę ruchu o dużym nasileniu, ale jest niższa niż w przypadku ciężkiego metra (definicja zaproponowana na podstawie definicji „kolei lekkiej” wg Dyrektyw Parlamentu Eurointeroperacyjności systemu kolei w Unii Europejskiej [13]).

Monorail - odmiana lekkiego metra oparta o jedna szynę, która jest jedynym podparciem i prowadnica (definicja zaproponowana na podstawie definicji monoraila zawartej w Rozporządzeniu Komisji (UE) [14]).

APM (Automated People Mover) - odmiana lekkiego 
pacity ensures heavy traffic, but is lower than in the case of heavy metro (the definition proposed on the basis of the definition of "light rail" according to the Directive of the European Parliament and of the Council on railway safety [12] and on the interoperability of the rail system within the European Union [13]).

Monorail - light meter variant based on one rail, which is the only support and guide (definition proposed on the basis of the monorail definition included in the Commission Regulation (EU) [14]).

APM (Automated People Mover) - a variant of the light metro - a fully automated, separate transport system for the movement of people with vehicles moving on a railroad with exclusive right of way. The term APM is used to describe transportation systems serving relatively small areas such as airports, downtown districts, or amusement parks (definition proposed from the definition of APM in the American Society of Civil Engineers [15]).

Tram - a vehicle intended for the transport of people or goods powered by electricity, running on rails on public roads (definition according to the road traffic act of 20 June 1997 [16]).

Fast tram - a type of urban transport system for the transport of people powered by electricity, the vehicles of which run on rails, with a limited collision with other subsystems, while single-level crossings with a traffic light system are allowed, giving absolute priority to the rail vehicle. Fast tram lines can run in tunnels, on surface, and on estacades. This system is characterized by a higher commercial speed and greater distances between stations than a typical tram system (definition proposed on the basis of the definition of a tram according to the road traffic act of 20 June 1997 [16]).

At the same time, it is proposed to modify the definition of other rail transport in the act on public collective transport, because the act qualifies metro and monorail to other rail transport, but distinguishes monorail as other than metro means of transport [17]:

Other rail transport - the transport of people by a means of transport that runs on rails or railway tracks, including a tram or metro (including a means of transport that runs on one rail, such as a monorail or APM), or the transport of people by means of transport that runs on air or magnetic pillows, other than railway transport and rope-off-road transport (definition developed by the Departments of Transport of the Warsaw University of Technology and of Transport and Aviation Engineering of the Silesian University of Technology).

\section{SUMMARY AND CONCLUSIONS}

Changes in the legislation should concern on introduction new means of transport such as monorail, APM, and light metro (all defined as types of metro) to the acts. The lack of a general definition of metro in the metra - w pełni zautomatyzowany wydzielony system transportowy służący do przemieszczania osób, z pojazdami poruszającymi się po drodze szynowej z wyłącznym pierwszeństwem przejazdu. Termin APM jest używany do opisania systemów transportowych obsługujących stosunkowo małe obszary, takie jak lotniska, dzielnice śródmieścia lub parki rozrywki (definicja zaproponowana na podstawie definicji APM zawartej w normie American Society of Civil Engineers [15]).

Tramwaj - pojazd przeznaczony do przewozu osób lub rzeczy zasilany energią elektryczną, poruszający się po szynach na drogach publicznych (definicja wg ustawy z dnia 20 czerwca 1997 r. prawo o ruchu drogowym [16]).

Szybki tramwaj - rodzaj miejskiego systemu transportu przeznaczonego do przewozu osób zasilanego energią elektryczną, którego pojazdy poruszają się po szynach, cechujący się ograniczoną kolizyjnością z innymi podsystemami, przy czym dopuszcza się skrzyżowania jednopoziomowe z układem sygnalizacji świetlnej dającej bezwzględne pierwszeństwo pojazdowi szynowemu. Linie szybkiego tramwaju moga być prowadzone w tunelach, po powierzchni terenu i na estakadach. System ten charakteryzuje się wyższą prędkością komunikacyjną oraz większymi odległościami między przystankami niż typowy system tramwajowy (definicja zaproponowana na podstawie definicji tramwaju wg ustawy z dnia 20 czerwca 1997 r. prawo o ruchu drogowym [16]).

Jednocześnie proponuje się modyfikację definicji transportu innego szynowego w ustawie o publicznym transporcie zbiorowym, ponieważ ustawa kwalifikuje metro i monorail do innego transportu szynowego, ale rozróżnia monoraila, jako środek transportu inny niż metro [17]:

Transport inny szynowy - przewóz osób środkiem transportu poruszającym się po szynach lub torach kolejowych, w tym tramwajem lub metrem (w tym środkiem transportu poruszającym się po jednej szynie jak monorail, lub APM), lub przewóz osób środkiem transportu poruszającym się na poduszkach powietrznych lub magnetycznych, inny niż transport kolejowy i transport linowo-terenowy (definicja opracowana przez Wydziały Transportu Politechniki Warszawskiej oraz Transportu i Inżynierii Lotniczej Politechniki Śląskiej).

\section{PODSUMOWANIE I WNIOSKI}

Zmiany w prawodawstwie dotyczyć powinny wprowadzenia do ustaw nowych środków transportu jak monorail, APM i lekkie metro, zdefiniowanych jako odmiany metra. Brak ogólnej definicji metra w ustawach o transporcie kolejowym i publicznym transporcie zbiorowym może w przyszłości utrudniać wprowadzenie nowych rozwiązań do realizacji w ramach projektów transportowych dużych miast. Stosowane 
acts on railway transport and public collective transport may hinder the introduction of new solutions to transport projects in large cities in the future. The definitions currently used in Polish legislation do not cover all means of transport that are already commonly used in many places in the world and in Europe.

Devices and systems used in the metro should have a type approval certificate, and the certification process is presented in "Ordinance 720" [18]. In the process of certification in Poland, transport solutions like monorail and APM, it is proposed to base on certification processes, and the recognition of the results of research and operational tests carried out for certification in other European Union countries.

The conducted technical analysis of new transport solutions like monorail and APM, and their current legal status in Poland allows for the following conclusions:

1. Transport solutions of the monorail and APM type, due to their structural, functional and operational similarities, and due to their high level of complexity, should be classified as metro variants, and they are assigned, in accordance with the act on railway transport, to the President of the Office of Rail Transport, as the national safety authority.

2. In the current legal status, it is possible to allow the operation of monorail and APM without the need to introduce critical changes in the legislation, but taking into account all analyzed types of metro, it is recommended to supplement and introduce new provisions in the laws on railway transport and public collective transport in the field of definition.

3. In the certification process of monorail and APM transport solutions in Poland, it is proposed to base on certification processes carried out in other European Union countries and the recognition of the results of tests and operational tests carried out for the purposes of certification. aktualnie $w$ polskim prawodawstwie definicje nie wyczerpują wszystkich środków transportu, które są już powszechnie stosowane w wielu miejscach na świecie i Europie.

Urządzenia i systemy stosowane w metrze powinny posiadać świadectwo dopuszczenia do eksploatacji typu, a proces certyfikacji przedstawiony jest w „Rozporządzeniu 720 " [18]. W procesie certyfikacji w Polsce rozwiązań transportowych typu monorail i APM proponuje się oprzeć na procesach certyfikacji przeprowadzonych w innych krajach Unii Europejskiej i uznaniu wyników badań i prób eksploatacyjnych przeprowadzonych na potrzeby certyfikacji.

Przeprowadzona analiza techniczna nowych rozwiązań transportowych i aktualnego stanu prawnego w Polsce pozwala na wyciągniecie następujących wniosków:

1. Rozwiązania transportowe typu monorail i APM, ze względu na podobieństwa konstrukcyjne i funkcjonalno-eksploatacyjne oraz ze względu na ich wysoki poziom złożoności należy zakwalifikować jako odmiany metra, i przypisane są one, zgodnie z ustawą o transporcie kolejowym, do Prezesa Urzędu Transportu Kolejowego, jako organu nadzoru bezpieczeństwa.

2. W obecnym stanie prawnym możliwe jest dopuszczenie do eksploatacji rozwiązań transportowych typu monorail i APM bez konieczności wprowadzania krytycznych zmian w ustawodawstwie, ale biorąc pod uwagę wszystkie analizowane rodzaje metra, zalecane jest uzupełnienie i wprowadzenie nowych zapisów w ustawach o transporcie kolejowym i publicznym transporcie zbiorowym w zakresie definicji.

3. W procesie certyfikacji w Polsce rozwiązań transportowych typu monorail i APM proponuje się oprzeć na procesach certyfikacji przeprowadzonych w innych krajach Unii Europejskiej i uznaniu wyników badań i prób eksploatacyjnych przeprowadzonych na potrzeby certyfikacji.

\section{Bibliography / Bibliografia}

1. Mazurek T., Kubalski J.: Komunikacja miejska. WKŁ Warszawa 1968 r.

2. Ostaszewicz J., Taraj M.: Szybka komunikacja miejska. WKŁ Warszawa 1979 r.

3. Podoski J.: Tramwaj szybki. Projektowanie i eksploatacja. WKŁ Warszawa 1983 r.

4. Podoski J.: Transport w miastach. WKŁ Warszawa 1985 r.

5. Ustawa z dnia 16 grudnia 2010 r. o publicznym transporcie zbiorowym (Dz.U 2017 poz. 2136 z późn. zm.).

6. Bombardier Transportation: Monorail_Planning_Guide_SYS_04_2014.

7. Bombardier Transportation: APM_Planning_Guide-10904-SȲS-0̄2-2011.

8. Bombardier Transportation: Innovia Metro 300 System.

9. Alstom: AXONIS specyfikacja techniczna.

10. Ustawa z dnia 28 marca 2003 r. o transporcie kolejowym (Dz.U. 2003 nr 86 poz. 789 z późn. zm.).

11. Rozporzqdzenie Ministra Infrastruktury (859) z dnia 17 czerwca 2011 r. w sprawie warunków technicznych, jakim powinny odpowiadać obiekty budowlane metra i ich usytuowanie (Dz. U. $2011 \mathrm{Nr} 144$, poz. 859).

12. Dyrektywa Parlamentu Europejskiego $i$ Rady (UE) 2016/797 z dnia 11 maja 2016 r. w sprawie interoperacyjności systemu kolei w Unii Europejskiej.

13. Dyrektywa Parlamentu Europejskiego i Rady (UE) 2016/798 z dnia 11 maja 2016 r. w sprawie bezpieczeństwa kolei. 
14. Rozporzqdzenie Komisji (UE) NR 102/2011 z dnia 4 lutego 2011 r. zmieniajace rozporzqdzenie (UE) $n r$ 1089/2010 w sprawie wykonania dyrektywy 2007/2/WE Parlamentu Europejskiego $i$ Rady $w$ zakresie interoperacyjności zbiorów i ustug danych przestrzennych.

15. American Society of Civil Engineers - ASCE Standard ANSI/ASCE/T\&DI 21-05 Automated People Mover Standards - Part 1.

16. Ustawa z dnia 20 czerwca 1997 r. prawo o ruchu drogowym (Dz. U. 1997 Nr 98 poz. 602 z późn. zm.).

17. Ćwiek J., Żochowska R., Mtyńczak J., Karoń G., Folęga P., Wierzbicki Ł., Surma S.: Analiza stanu prawnego i technicznego dotyczqca możliwości wdrożenia w Polsce rozwiazań transportowych Innovia 300 typu Monorail, APM $i$ lekkie metro firmy Bombardier Transportation $w$ zakresie podsystemów infrastruktura i tabor. Praca naukowo-badawcza, Wydział Transportu i Inżynierii Lotniczej, Politechnika Ślaska, Katowice 2020.

18. Rozporzqdzenie Ministra Infrastruktury i Rozwoju (720) z dnia 13 maja 2014 r. w sprawie dopuszczania do eksploatacji określonych rodzajów budowli, urzq̨dzeń i pojazdów kolejowych (Dz.U. 2014 poz. 720). 